\title{
Immune Modulation Plus Tumor Ablation: Adjuvants and Antibodies to Prime and Boost Anti-Tumor Immunity In Situ
}

\author{
Renske J. E. van den Bijgaart ${ }^{1 \dagger}$, Fabian Schuurmans ${ }^{1 \dagger}$, Jurgen J. Fütterer ${ }^{2,3}$, \\ Marcel Verheij ${ }^{1}$, Lenneke A. M. Cornelissen ${ }^{1}$ and Gosse J. Adema ${ }^{1 *}$ \\ ${ }^{1}$ Radiotherapy \& Oncolmmunology Laboratory, Department of Radiation Oncology, Radboud University Medical Center, \\ Nijmegen, Netherlands, ${ }^{2}$ Department of Medical Imaging, Radboud University Medical Center, Nijmegen, Netherlands, \\ ${ }^{3}$ Department of Robotics and Mechatronics, University of Twente, Enschede, Netherlands
}

\section{OPEN ACCESS}

Edited by:

Alan Graham Pockley, Nottingham Trent University,

United Kingdom

Reviewed by:

Graham Robert Leggatt, The University of Queensland, Australia

Yona Keisari,

Tel Aviv University, Israel

*Correspondence:

Gosse J. Adema

gosse.adema@radboudumc.nl

${ }^{t}$ These authors have equally contributed to this work

Specialty section:

This article was submitted to

Cancer Immunity and Immunotherapy,

a section of the journal

Frontiers in Immunology

Received: 14 October 2020 Accepted: 22 March 2021 Published: 14 April 2021

Citation:

van den Bijgaart RJE, Schuurmans F, Fütterer JJ, Verheij M, Cornelissen LAM and Adema GJ (2021) Immune

Modulation Plus Tumor Ablation:

Adjuvants and Antibodies to Prime and Boost Anti-Tumor Immunity In Situ.

Front. Immunol. 12:617365. doi: 10.3389/fimmu.2021.617365
In situ tumor ablation techniques, like radiotherapy, cryo- and heat-based thermal ablation are successfully applied in oncology for local destruction of tumor masses. Although diverse in technology and mechanism of inducing cell death, ablative techniques share one key feature: they generate tumor debris which remains in situ. This tumor debris functions as an unbiased source of tumor antigens available to the immune system and has led to the concept of in situ cancer vaccination. Most studies, however, report generally modest tumor-directed immune responses following local tumor ablation as stand-alone treatment. Tumors have evolved mechanisms to create an immunosuppressive tumor microenvironment (TME), parts of which may admix with the antigen depot. Provision of immune stimuli, as well as approaches that counteract the immunosuppressive TME, have shown to be key to boost ablation-induced anti-tumor immunity. Recent advances in protein engineering have yielded novel multifunctional antibody formats. These multifunctional antibodies can provide a combination of distinct effector functions or allow for delivery of immunomodulators specifically to the relevant locations, thereby mitigating potential toxic side effects. This review provides an update on immune activation strategies that have been tested to act in concert with tumor debris to achieve in situ cancer vaccination. We further provide a rationale for multifunctional antibody formats to be applied together with in situ ablation to boost anti-tumor immunity for local and systemic tumor control.

Keywords: tumor ablation, immune activation, in situ cancer vaccination, multifunctional antibodies, combination therapy

\section{INTRODUCTION}

Vaccines have been extremely successful in preventing infectious diseases by training the immune system to recognize and destroy pathogens. Conventional vaccines comprise of antigen(s) often supplemented with immune adjuvants to support the induction of an effective immune response. Besides, adjuvants can function as a slow release system, ensuring prolonged and continuous 
presentation and stimulation of the immune system (1). The application of vaccines to cancer is an obvious extension of their utility, and many diverse vaccination strategies are under development. An interesting novel approach is the in vivo loading and activation of dendritic cells (DCs) with tumor antigens released following in situ tumor ablation.

Tumor ablation techniques are successfully applied for the treatment of different malignancies. Although diverse in technology and mechanism of action, all ablative techniques lead to in situ availability of ablated tumor material (Figure 1A). The tumor debris released upon ablation functions as an antigen depot representing the tumors' antigenic repertoire. Together with the simultaneous release of bioactive molecules, such as damage-associated molecular patterns (DAMPs), this has led to the concept of in situ cancer vaccination. Indeed, tumor antigens were observed in DCs residing in draining lymph nodes (dLNs) following ablation (2). Immune responses induced by ablation as stand-alone treatment are documented, however, tend to be incapable of evoking robust sustainable anti-tumor immunity. This is further evidenced by the scarce reports of spontaneous regression of untreated distant metastatic sites following ablation, the so-called 'abscopal effect' $(3,4)$. Therefore, it has been proposed by us and others to initiate and boost ablationinduced anti-tumor immunity by combining ablation with immune activation strategies (5-7). An outstanding question in the field remains which immune activation strategies effectively combine with in situ tumor ablation.

Examples of immune activation strategies that are mostly applied together with tumor ablation include stimulation with pattern recognition receptor (PRR) agonists, adjuvants and agonistic antibodies. However, tumors have evolved mechanisms to create an immunosuppressive tumor microenvironment (TME), parts of which may admix with the antigen depot upon ablation. Development of a successful in situ cancer vaccine thus requires immune activation strategies to boost immunity and approaches that counteract the

\section{A}

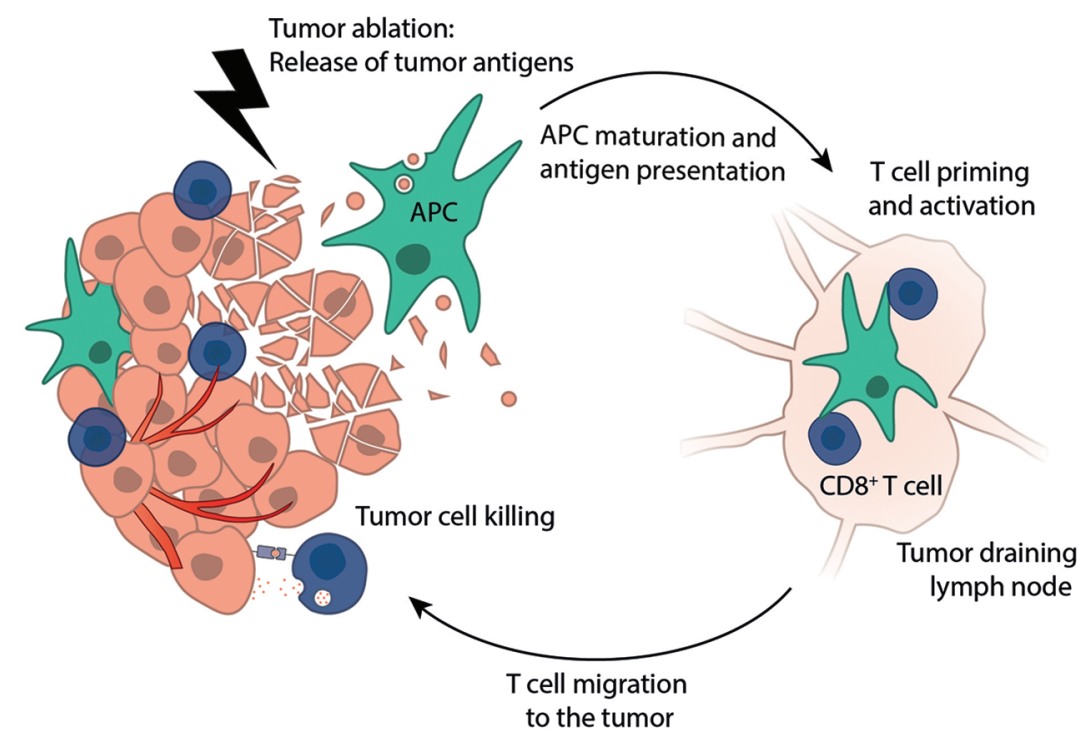

B

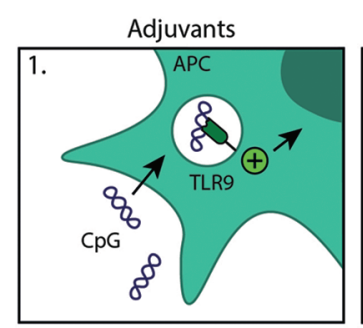

Agonistic antibodies

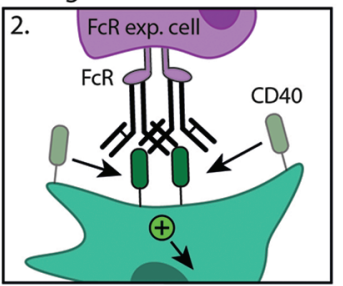

Scavenging of inhibitory cytokines

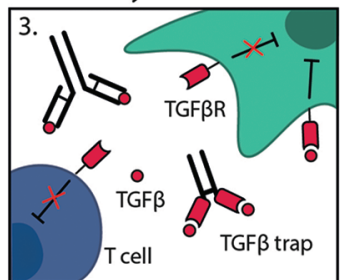

Immune checkpoint blockade (ICB)

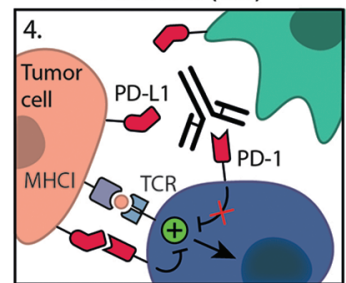

FIGURE 1 | Immune activation strategies plus tumor ablation to create in situ cancer vaccines. (A) Tumor ablation results in the release of tumor antigens available for uptake by antigen-presenting cells (APC), such as DCs. These antigens are (cross-)presented on MHC molecules to T cells in the dLN, resulting in T cell priming and activation. Activated T cells subsequently migrate to the destructed tumor, as well as distant metastases, where they kill remaining tumor cells. (B) Immune response induction is boosted by exogenous administration of immune stimulating compounds like 1. adjuvants (e.g. CpG) or 2. agonistic antibodies (e.g. anti-CD40 $\mathrm{mAb}$, crosslinking by Fc-receptor expressing cells) that can work synergistically with tumor ablation in creating effective, mature DCs. Furthermore, several approaches can be exploited to counteract the immunosuppressive TME, such as 3. scavenging of inhibitory cytokines (e.g. anti-TGF $\beta$ mAb or TGF $\beta$ trap) or 4. immune checkpoint blockade (ICB, e.g. anti-PD-1 mAb), both to enhance the anti-tumor immune response. 
immunosuppressive TME like monoclonal antibodies (mAbs) against inhibitory immune checkpoints, inhibition of immunosuppressive cells like regulatory $\mathrm{T}$ cells (Treg) or myeloid derived suppressor cells (MDSC) or by scavenging anti-inflammatory cytokines, such as transforming growth factor beta (TGF $\beta$ ).

Delivery of these immunomodulators to the relevant locations, i.e. the tumor and tumor dLNs, is often essential for enhancing anti-tumor specific immune responses following ablation. Targeting also mitigates potential toxic side-effects. Antibodies can exhibit tumor targeting abilities, either through their specificity for tumor antigens or ablation-associated factors, such as extracellular DNA and histones. Recent advances in antibody engineering enabled the creation of novel antibody formats with multiple functions, such as bispecific antibodies and protein-linked antibodies (8). Multifunctional antibodies create new opportunities to enhance anti-tumor immunity following in situ tumor ablation techniques.

Here, we review immune activation strategies and approaches that counteract the immunosuppressive TME that have been combined with in situ tumor ablation. Furthermore, we postulate new combination strategies involving multifunctional antibody formats to be applied together with in situ ablation to boost the anti-tumor immunity for local and systemic tumor control.

\section{IN SITU TUMOR ABLATION}

During the last decades, there has been widespread interest in the development and refinement of ablation techniques for local treatment of cancers. The primary goal of tumor ablation is to destroy malignant cells within a designated volume through the local deposition of energy via different approaches, e.g. ionizing radiation or extreme temperatures. Radiotherapy (RT) has been a strong pillar in cancer therapy and the majority of cancer patients undergo RT at one point during treatment (9). The anti-tumor efficacy of RT has been attributed to its capacity to induce DNA damage, as well as through increased recognition of tumor cells by the immune system. Stereotactic ablative body radiotherapy (SABRT) allows for the delivery of ablative radiation doses. An exciting development in radiation oncology is the magnetic resonance linear accelerator (MR-Linac) which enables high precision ablative RT under real-time MR-guidance, providing better target control while sparing the surrounding healthy tissues including LNs (10). MR-guided RT is a promising tool to answer key questions in the field of immuno-radiobiology, and will help to understand how to bring dose and fractionation schedules into an immunologically active range.

Different from RT, most other tumor ablation techniques rely on extreme temperatures for cellular destruction. Cryoablation applies extremely cold temperatures, whereas heat-based thermal ablation modalities, including radiofrequency ablation (RFA), microwave ablation (MWA), laser ablation and thermal highintensity focused ultrasound (HIFU) employ different sources of energy to heat the target region $(7,11)$. Cells in the core of the ablation zone are subjected to lethal temperatures; up to $-180^{\circ} \mathrm{C}$ for cryoablation inducing hypothermic necrosis and $>60^{\circ} \mathrm{C}$ for thermal ablation resulting in protein denaturation and coagulative necrosis. Cells in the periphery of the ablation zones are exposed to sublethal temperatures and either undergo apoptotic cell death or are able to recover from reversible injury (12). In contrast to thermal HIFU ablation, HIFU can be used to generate mechanical damage as a result of acoustic cavitation, with minimal thermal damage, also known as (boiling) histotripsy or mechanical HIFU (12-14).

Besides their ability to kill tumor cells, ablation modalities unveil an array of tumor antigens. Several studies have emphasized the importance of neoantigens arising due to tumor-specific DNA mutations in the recognition of tumor cells by the immune system $(15,16)$. Each ablation technique results in a unique tumor antigenic fingerprint. Heat-based thermal ablation results in protein denaturation and coagulative necrosis, possibly reducing the availability of intact tumor antigens for the immune system. Furthermore, the coagulative necrosis destroys the structure and vasculature of tumors, thereby affecting the ability of immune cells to reach and interact with the antigen depot (17). Mechanical HIFU, on the other hand, will result in complete liquification of the tissue, which is effectively removed via drainage or absorbed as part of the physiologic healing response $(18,19)$. For cryoablation it has been reported that many native antigen structures are preserved (20). Furthermore, cryoablation has shown to induce polyclonality and intra-tumoral T cell repertoire remodeling (21). How each ablation technique affects handling and processing of antigenic materials by antigen-presenting cells (APCs) and which ablation technique results in the most effective release of immunogenic (neo)antigens remains to be investigated.

During efforts of the body to clear this tumor debris, there is a time frame in which the immune system can be triggered towards antigens from the antigen depot (Figure 1A). In fact, the presence of the antigen depot is a prerequisite for the development of an anti-tumor immune response, as protective immunity failed to develop upon surgical removal of cryoablated tumors (2). Cytokines and endogenous danger signals, such as DAMPs, are readily released from the ablated tumor, which may contribute to immune activation. On the other hand, ablation will also lead to a physiological wound healing response that regulates and maintains immunological tolerance toward the damaged tissue. In practice, ablation induced immunomodulation alone appears (often) insufficient to generate consistent protective anti-tumor immunity. Therefore, interest has shifted towards exploring the potential synergy between ablative techniques and immune activation strategies. Strong systemic immunity will be critical for controlling residual disease at the site of ablation and for eradicating distant metastases.

\section{ANTIGEN PRESENTING CELLS AND IMMUNE ACTIVATING STRATEGIES}

DCs, the most potent APCs of the immune system, have the unique ability to initiate and direct immune responses. DCs in the vicinity of or recruited to the local ablation site acquire and 
process tumor antigens, and subsequently present them to naïve $\mathrm{T}$ cells (22). Alternatively, tumor antigens may passively enter the circulation or lymphatics and can be transported to LNs where they can be taken up by LN-resident DCs. DCs can crosspresent peptides derived from such extracellular antigens to MHC I restricted $\mathrm{CD}^{+} \mathrm{T}$ cells. In addition to the initial interaction between the TCR and MHC-molecules on DCs, costimulation (signal 2) and cytokines (signal 3) are important for initiation of antigen-specific T cells. Thus, proper DC maturation is essential for efficient immune response induction. The ability to load and mature DCs directly in situ by tumor ablation plus immune activation is thus an appealing strategy to develop a cancer vaccine.

\section{Adjuvants}

Adjuvants can boost the magnitude and duration of the adaptive immune response. One of the ways through which adjuvants act is by serving as, or inducing, DAMPs and/or pathogenassociated molecular patterns (PAMPs) that trigger PRRs on immune cells resulting in their activation. Alternatively, adjuvants can function as slow release system. Although numerous different adjuvants exist, we will focus on nucleic acid-sensing PRR agonists, as well as the potential of saponinbased adjuvants (SBAs) applied in combination with in situ tumor ablation.

\section{Toll-Like Receptor (TLR) Agonists}

TLR triggering is one of the most potent inducers of DC maturation in vivo as evidenced by their capacity to upregulate co-stimulatory molecules and enhanced production of proinflammatory cytokines needed for DC-mediated $\mathrm{T}$ cell priming. The nucleic acid-sensing TLRs include TLR9, TLR3 and TLR7/8. CpG oligodeoxynucleotides (CpG) are short unmethylated single stranded-synthetic DNA molecules, which were one of the first adjuvants to be combined with in situ tumor ablation (2). Pioneering work combining CpG with cryoablation in a B16OVA melanoma model showed the induction of longterm immune memory, evidenced by a $50 \%$ survival of mice subjected to a re-challenge. The survival benefit was absent in the single treatment groups. Additional studies showed the antitumor effect is dependent on plasmacytoid DCs (pDCs), which stimulate the ability of conventional type 1 DCs (cDC1s) to prime naïve $\mathrm{CD} 8^{+} \mathrm{T}$ cells $(23,24)$. A prerequisite for the synergy between cryoablation and $\mathrm{CpG}$ is the co-localization of the antigen and $\mathrm{CpG}$ within a DC. Therefore, the timing and location of $\mathrm{CpG}$ administration relative to the release of tumor antigens by tumor ablation is of importance for protective antitumor immunity $(25,26)$. The beneficial effects of CpG with cryoablation have also been observed in a mammary adenocarcinoma model (27). CpG combinations with other ablative therapies, such as RT and HIFU, have also proven successful (28-30). Interestingly, the combination of thermal HIFU ablation of mammary adenocarcinoma tumors with $\mathrm{CpG}$ plus anti-PD-1 increased the number of unique CDR3 rearrangements in the $\mathrm{T}$ cell repertoire at distal tumors, indicating the generation of $\mathrm{T}$ cells specific for a broad range of different tumor antigens (30).
The synthetic dsRNA analog polyinosinic-polycytidylic acid (Poly-IC) is a ligand for TLR3 and has shown promising preclinical results in combination with a minimal 9 Gy single dose RT. The combination treatment greatly reduced tumor growth at primary and abscopal sites and enhanced survival in different mouse models (31-33). The Poly-IC plus RT combination treatment of A20 lymphoma tumors plus intratumoral (i.t.) FLT3L injections further increased DC recruitment and synergistically induced adaptive anti-tumor immunity (33). Mechanistic studies revealed that RT increased serum levels of high mobility group box 1 (HMGB1), a known DAMP in vivo. HMGB1 potentiated the Poly-IC induced DC maturation, demonstrating the potential of DAMP plus TLR adjuvant combination strategies (33).

TLR7/8 agonists gained fame through Imiquimod, an adjuvant formulation topically applied in the treatment of skin cancers (34). Topical Imiquimod application, as well as systemic administration (encapsulated in nanoparticles (NP)), in combination with cryoablation or $\mathrm{RT}$, resulted in improved tumor control at primary and distant sites in numerous murine cancer models (35-38). As with CpG, TLR7 agonists are believed to act primarily through activation of pDCs (39). The results of a phase I/II clinical trial investigating the efficacy of topical imiquimod application to breast cancers skin metastases in conjunction with RT are currently on their way (NCT01421017). Altogether, TLR agonists can be employed as powerful adjuvants along with ablation to generate effective antitumor immunity.

\section{STING Agonists}

DNA normally resides in the nucleus and mitochondria; hence, its presence in the cytoplasm serves as a danger signal. This aberrant localization of DNA is sensed by the DNA binding enzyme cyclic GMP-AMP synthase (cGAS). Upon recognition, cGAS dimerizes and stimulates the production of cyclic-GMPAMP (cGAMP) which can directly bind stimulator of interferon genes (STING) resulting in type I interferon (IFN) production (40). Cytoplasmic DNA sensing through the cGAS-STING pathway plays a pivotal role in APC activation following phagocytosis (41).

Synthetic analogues of 2'3'-cGAMP, a stable variant of the second messenger produced by cGAS are used as STINGactivating agents. Combinations of such analogues with ablative therapy are scarce and limited to one study by Deng et al. which showed i.t. injection of 2'3'-cGAMP in combination with a single 20 Gy RT dose greatly reduced tumor growth compared to either treatment alone and resulted in complete tumor rejection in $70 \%$ of the mice (42). Besides cGAMP analogues, an interesting discovery are the STING activating properties of PC7A nanovaccine, which consist of E7 peptide or OVA peptide-loaded micelle NPs binding to STING (43). Half of the mice treated with the combination of PC7A and 20 Gy RT were tumor free 60 days after tumor inoculation, compared to none of the mice from the single treatment groups. Treatment efficacy showed to be depended on STING signaling and increased tumor reactive $\mathrm{CD}^{+} \mathrm{T}$ cells were observed (43). RT induces cytoplasmic DNA and micronuclei formation which can 
activate the cGAS/STING pathway. It has been shown that cGAS/STING dependent DNA sensing in DCs is essential in triggering adaptive immunity following RT (42). Other studies, however, report that also cancer cell intrinsic cGAS activation can be important in the induction of an adaptive immune response following RT. cGAMP produced by cancer cells was shown to be transported to DCs via gap junctions, resulting in STING activation in these DCs and subsequent type I IFN production (44). One explanation for the beneficial effect of exogenous STING ligand administration on top of RT induced activation could be the numerous regulatory mechanisms that control cGAS-STING pathway activation. TREX1 is a RT inducible dsDNA exonuclease that attenuates the STING signaling cascade (45). More recently, BAF and C9orf72 have been implicated in the regulation of myeloid STING activation $(46,47)$. It would therefore be interesting to determine if these regulatory mechanisms are upregulated following tumor ablation and whether stimulation of the cGAS/STING pathway upon ablation would be beneficial to achieve an in situ cancer vaccine.

However, some degree of caution should be taken as tumor cell intrinsic cGAS/STING activation has been linked to metastases formation (48). This highlights that an appropriate balance and possibly myeloid cell specific STING pathway activation may be required for optimal anti-tumor immunity.

\section{Saponin-Based Adjuvants}

Antigen cross-presentation by DCs is crucial for $\mathrm{CD}^{+} \mathrm{T}$ cell mediated anti-tumor immunity. Although most conventional adjuvants are unable to boost $\mathrm{CD}^{+} \mathrm{T}$ cell responses, SBAs are known to be superior in inducing antigen cross-presentation by DCs (1). Cryoablation with co-injection of SBAs, leads to an extremely potent systemic anti-tumor response. These effects are dependent on the ability of SBAs to induce cross-presentation, specifically in $\mathrm{CD}_{11 \mathrm{~b}^{+}}$DCs (49). Additional administration of CpG with SBAs following cryoablation created a highly effective in situ cancer vaccine and resulted in the generation of multifunctional $\mathrm{T}$ cells able to produce high amounts of proinflammatory cytokines (50). The exact mechanism through which SBAs induce cross-presentation remains elusive, although lipid bodies are found to play a crucial role (49). Interestingly, monocyte-derived CD11 $\mathrm{b}^{+}$DCs have been implicated to be better in the activation and induction of memory $\mathrm{CD} 8^{+} \mathrm{T}$ cells as compared to $\mathrm{CDC1}(51,52)$. Therefore, SBAs might be specifically potent in inducing long term immune memory. Besides cryoablation also other ablation therapies, such as RT and HIFU, are of interest for their potential synergy with SBAs.

Altogether, adjuvants are suitable candidates to be applied with tumor ablation to generate an in situ cancer vaccine (Figure 1B1). More detailed knowledge about effective adjuvant-ablation strategies, such as correct timing and the involved immune subsets, is required to efficiently prime and boost antitumor immunity.

\section{Agonistic Antibodies}

DCs can further be activated by cell-cell contact and subsequent signaling via members of the immunoglobulin domain- containing receptor family, especially the tumor necrosis factor (TNF) receptor family, such as CD40/CD40 ligand (CD40L) and CD27/CD70. CD40 engagement on DCs by $\mathrm{CD} 40 \mathrm{~L}$ expressed by $\mathrm{CD} 4^{+} \mathrm{T}$ helper cells or agonistic CD40 $\mathrm{mAbs}$ trigger $\mathrm{DC}$ activation to provide signals for the licensing and expansion of $\mathrm{CD}^{+}$cytotoxic $\mathrm{T}$ cells $(53,54)$. CD40 agonistic $\mathrm{mAbs}$ have shown synergistic effects in combination with RT. Addition of agonistic anti-CD40 mAb to $10 \mathrm{~Gy}$ RT increased survival of mice inoculated with EG7 tumors to 80\% as compared to $40 \%$ (anti-CD40) and 20\% (RT) for the monotherapy regimens (55). All surviving mice treated with the combination therapy were resistant to a subsequent rechallenge, indicative for immune memory. Similar results have been achieved using a Panc02 tumor model where combination therapy not only limited primary tumor growth, but also growth of an untreated contralateral tumor (56). In the latter model, agonistic CD40 therapy worked best when combined with a hypo-fractionated RT regimen (5 Gy single dose). Moreover, timing of anti-CD40 mAb administration relative to RT treatment was crucial for its efficacy as administration prior to RT did not show beneficial effects (57). TLR agonists, such as $\mathrm{CpG}$ and Poly-IC, are known to upregulate the expression of CD40 on human pDCs as well as myeloid DCs $(58,59)$. Poly-IC is especially interesting as in combination with anti-CD40 mAb it induced the highest percentage of OVAspecific $\mathrm{T}$ cells relative to other TLR agonists (60). This can possibly be explained by the upregulation of CD70, the ligand for the $\mathrm{T}$ cell co-stimulatory receptor $\mathrm{CD} 27$, following stimulation with Poly-IC and anti-CD40 mAb (61). It would therefore be interesting to investigate the efficacy of the triple combination of agonistic mAbs plus adjuvants and ablative therapies.

Besides DCs, also $\mathrm{T}$ cells express multiple co-stimulatory receptors, including CD27, OX40 and CD137 (4-1BB). Ligation of these receptors delivers co-stimulatory signals necessary for full $\mathrm{T}$ cell activation (62-65). RT induces upregulation of OX40 expression on $\mathrm{CD}^{+}$and $\mathrm{CD}^{+} \mathrm{T}$ cells as well as $\mathrm{CD} 137$ on $\mathrm{CD}^{+}$tumor infiltrating $\mathrm{T}$ cells and thus works in concert with agonistic OX40 or CD137 therapy (6668). CD137 expressing $\mathrm{CD}^{+} \mathrm{T}$ cells are also highly positive for PD-1, and RT plus agonistic CD137 therapy benefits from additional anti-PD-1 mAbs to block negative feedback by PDL1 (69). Combining multiple different immune activation strategies which complement each other is an appealing approach to further stimulate the immune response. Noteworthy, combinations of CpG plus RT, agonistic OX40 mAbs plus RT as well as CpG plus agonistic OX40 mAbs have shown synergistic effects in their ability to limit tumor growth, making the combination of $\mathrm{CpG}$, agonistic OX40 with RT or other ablative therapies an interesting approach to explore (29, 70, 71).

To date, all agonistic antibodies investigated have shown promising results in combination with RT and the addition of adjuvants might further improve their function (Figure 1B2). Whether these agonistic antibodies also synergize with other ablative modalities remains to be determined. 


\section{COUNTERACTING THE IMMUNOSUPPRESSIVE TME}

Tumors have evolved several mechanisms to instigate an immunosuppressive TME, parts of which may admix with the antigen depot upon ablation. Successful in situ cancer vaccines may, in addition to immune activation strategies, also require approaches that counteract the immunosuppressive microenvironment. Immune suppression networks consist of immune suppressive cells including Tregs and MDSCs, immunosuppressive cytokines like TGF $\beta$ and IL-10, as well as enhancement of co-inhibitory molecules such as CTLA-4 or PD1 on T cells. Targeting immunosuppressive cells has emerged as important approach to counteract the immunosuppressive TME, which is discussed in detail elsewhere (72-74). In the next sections, we will discuss strategies to counteract the immunosuppressive molecules, with a focus on cytokine and immune checkpoint blockade, applied together with in situ tumor ablation.

\section{Immunosuppressive Cytokines}

Immune suppressive cytokines, such as TGF $\beta$ and IL-10, are a major obstacle in generating effective anti-tumor immunity. They are often produced by tumor cells and immune suppressive cell subsets, such as Tregs and MDSC (75). RT is known to increase the amount of active TGF $\beta$. TGF $\beta$ is initially produced in its latent form containing a pro-domain, dissociation of this domain makes the protein become active. Oxygen radicals produced following RT promote this dissociation resulting in more active $\operatorname{TGF} \beta(76,77)$. Thermal ablation at temperatures above $65^{\circ} \mathrm{C}$ can lead to denaturation of proteins, potentially including part of immune suppressive cytokines, such as TGF $\beta$ or IL-10. Strategies that block inhibitory signaling through antagonistic antibodies, as well as scavenging of inhibitory cytokines themselves are ways to alleviate their inhibitory function (Figure 1B3).

Scavenging of TGF $\beta$ using antibodies limits growth of treated and untreated tumors following $5 \times 6$ Gy RT (78). This combination therapy increased DC maturation evidenced by an increase in $\mathrm{CD} 40^{+} \mathrm{CD} 70^{+}$DCs. Furthermore, the combination increased the production of IFN $\gamma$ by dLN-derived $\mathrm{CD} 8^{+} \mathrm{T}$ cells following ex vivo tumor antigen stimulation. Lastly, the percentage of $\mathrm{PD}-1^{+}$and $\mathrm{PD}-\mathrm{L} 1 / 2^{+}$cells in the tumor increased upon combination therapy, highlighting the induction of additional immune escape mechanisms. Inclusion of anti-PD-1 mAbs indeed further improved tumor control. Other successful TGF $\beta$ neutralizing approaches include recombinant TGF $\beta$ receptor (TGF $\beta R$ ) fused to an Fc-tail (79). The mechanism behind the anti-tumor effect of TGF $\beta$ scavenging is not solely immune mediated as TGF $\beta$ has pleiotropic functions, such as in wound healing and DNA repair, which could play a role with the anti-tumor effect $(80,81)$.

The cytokine IL-10 inhibits macrophage pro-inflammatory cytokine production, limits DC antigen presentation, and dampens $\mathrm{T}$ and NK cells effector function (82). Interestingly, some studies, however, report an increase in intra-tumoral cytotoxic $\mathrm{CD}^{+} \mathrm{T}$ cells upon IL-10 delivery to the tumor (83). This can be explained by the ability of IL-10 to limit IFN- $\gamma$ production by DCs, which is crucial for activation induced $\mathrm{T}$ cell apoptosis (84). All in all, efficacy of scavenging or blockade of anti-inflammatory factors will probably dependent on the choice of ablative therapy and state of the immune response when applied.

\section{Immune Checkpoints}

To shift the balance of the TME away from immunosuppression, mAbs can be applied to block inhibitory immune checkpoint receptors or their ligands (85). Relieving immunosuppression of adaptive immune cells has been extensively studied, and mAbs targeting CTLA-4 or PD-1/PD-L1 can enhance T cell immunity generated by ablation (Figure 1B4). CTLA-4 blockade allows CD80 and CD86 co-stimulatory molecules to be available for $\mathrm{CD} 28$, lowering the threshold for $\mathrm{T}$ cell activation (86). Anti-CTLA-4 mAbs also cause intra-tumoral Treg depletion or modulation of their suppressive functions $(87,88)$. CTLA-4 blockade synergized with different forms of thermal tumor ablation, resulting in significant amounts of active tumor-specific $\mathrm{T}$ cells and the ability to reject secondary or re-challenged tumors (89-91). Data from a pilot study conducted in breast cancer patients that received cryoablation and anti-CTLA- $4 \mathrm{mAb}$ showed good tolerability and promising efficacy (92). In the line of relieving immunosuppression, Treg depletion using anti-CD25 mAb enhances the anti-tumor response after RT, RFA and cryoablation, indicated by the increased presence of IFNy producing $\mathrm{T}$ cells after combination therapy in case of the latter two $(89,93,94)$. Currently various clinical trials are ongoing testing the potential of in situ ablation and checkpoint blockade in different solid malignancies.

PD-L1 is often highly expressed on tumor cells and tumor associated myeloid cells. PD-L1 can be induced by proinflammatory cytokines and is frequently upregulated in response to in situ tumor ablation $(95,96)$. Engagement of $\mathrm{PD}-1^{+} \mathrm{T}$ cells with its ligands leads to suppression of $\mathrm{T}$ cell effector mechanisms and mAbs that block the PD-1/PD-L1 axis are aimed at reinvigorating these exhausted $\mathrm{T}$ cells. RFA treatment of a localized tumor increased $\mathrm{T}$ cell infiltration in a distant tumor in both tumor-bearing mice as well as human patients (97). However, these tumors quickly overcame $\mathrm{T}$ cell cytotoxicity by inhibiting infiltrating T cells via upregulation of PD-L1 expression. In the murine setting, combining RFA with anti-PD-1 mAbs increased the tumor antigen-specific $\mathrm{T}$ cell response, and synergistically inhibited growth of distant tumors (97). Strikingly, incomplete RFA tumor ablation limited the efficacy of anti-PD-1 immunotherapy (98). The authors demonstrated that incomplete ablation induced local inflammation and resulted in accumulation of immunosuppressive myeloid cells in the residual tumor, which inhibited $\mathrm{T}$ cell functionality. Targeting the CCL2/ CCR2 pathway, responsible for the recruitment of these immunosuppressive myeloid cells, enhanced anti-tumor immunity in the residual tumor, and thereby overcame the resistance to anti-PD-1 therapy. 
Synergy between adaptive immune checkpoint blockade and RT has been demonstrated in multiple different preclinical tumor models (95, 99-102). However, RT dose and fractionation regimens as well as the timing of checkpoint blockade administration in conjunction with RT that would result in the most optimal anti-tumor immune response differ and warrant further study (103). Several other promising novel adaptive immune checkpoint molecules are actively being investigated, including TIM-3, LAG-3, TIGIT and VISTA (104), which could also be potential targets.

Recent studies have indicated that tumor cells exploit sialoglycan-Siglec interactions to modulate cytotoxic $\mathrm{T}$ cell as well as myeloid cell function, contributing to an immunosuppressive TME (105). Interference with the sialoglycan-Siglec axis by inhibiting the sialic acid synthesis pathway resulted in enhanced anti-tumor immunity and limited tumor outgrowth (106). Next to Siglec receptors, studies have highlighted innate immune checkpoints as interesting therapeutic targets. One of these checkpoints is the signal-regulatory protein $\alpha$ (SIRP $\alpha)$-CD47 axis. CD47 is often overexpressed on tumor cells and interacts with SIRP $\alpha$ on myeloid cells to trigger a 'don't eat me' signal (107). Blocking SIRP $\alpha$-CD47 interactions alleviates inhibitory signaling resulting in improved tumor cell clearance. Besides, murine models suggest that adaptive immunity contributes to tumor control upon targeting the SIRP $\alpha$-CD47 pathway (108-110). This can be a direct effect of the SIRP $\alpha$-CD47 pathway on T cell function or an indirect mechanism by which SIRP $\alpha-C D 47$ pathway blockade affects the capacity of myeloid cells to activate T cells. Interestingly, efficacy of CD47 blockade was shown to largely depend on DNA sensing, specifically in DCs (41). Interference with sialoglycan-Siglec interactions as well as innate immune checkpoints should be further explored in the context of in situ tumor destruction.

\section{FUTURE PERSPECTIVE: MULTIFUNCTIONAL ANTIBODY DEVELOPMENT AND IN SITU TUMOR ABLATION}

The tumor exists in a dynamic microenvironment that coinfluences anti-tumor immune responses. Strategies that simultaneously modulate multiple key processes in the anti-tumor immune response will likely work synergistically. Recent advances in antibody engineering have resulted in new antibody formats that can exert distinct effector functions (111). Besides, multifunctional antibodies can be used to direct immunomodulators specifically to the relevant locations, limiting systemic exposure and increasing tumor specificity. Multifunctional antibodies come in various molecular varieties, ranging from linked Fab fragments to full antibodies with an Fc-tail to preserve native antibody functions, such as antibody-dependent cellular cytotoxicity (ADCC)/ phagocytosis, complement-mediated lysis and improved circulation half-life (111). Multifunctionality can be achieved by combining different antibody variable domains, recognizing different epitopes, e.g. bispecific antibodies. Alternatively, receptors or immuno-modulatory molecules can be attached to antibodies via protein-linkers, acquiring multiple specificity in a different manner. Most of these multifunctional antibody formats are in (pre)clinical development and not yet applied in context with tumor ablation. We will here review antibody formats that could be beneficial in combination with tumor ablation to create an in situ cancer vaccine (Figure 2).

Bispecific antibodies come in various flavors and can target different antigens either on the same cell or on two different cell types. Most known bispecific antibodies in preclinical and clinical development are engaging T cells, binding CD3 and a relevant tumor antigen, to induce tumor cell killing (111). Alternatively, bispecific antibodies harboring an agonistic arm and a tumor targeting arm are developed $(112,113)$. These bispecific agonistic antibodies ensure tumor localization and allow cross-linking without the need for $\mathrm{Fc}$-receptors to exert its agonistic function (Figure 2.1). Instead they rely on a tumor antigen for crosslinking, making activation fully tumor cell dependent. For example, the bispecific antibody LB-1, which is specific for the tumor antigen MSLN and mouse CD40 showed preferential DC activation in vitro only when cultured with MSLN expressing tumor cells. In vivo application limited tumor growth of an MSLN expressing tumor to a similar extent as a conventional agonistic anti-CD40 mAb. The bifunctional molecule, however, showed less systemic activation and toxicity as compared to anti-CD40 therapy $(112,113)$. In addition to these there are also bispecific agonistic antibody constructs targeting two co-stimulatory receptors at once, CD137 and OX40, or a co-stimulatory receptor (OX40) and immune checkpoint (CTLA-4) $(114,115)$.

The success of immune checkpoint mAbs prompted the development of bispecific immune checkpoint formats, such as the PD-L1xErbB2 antibody (Figure 2.2). This bispecific antibody reduced tumor growth and increased tumor rejection rate compared to the combination of anti-PD-L1 and anti-ErbB2 $\mathrm{mAb}$ therapy, which was dependent on $\mathrm{CD}^{+} \mathrm{T}$ cells and IFN $\gamma$ (116). The bispecific antibody was constructed with a mIgG2a Fc backbone and the authors describe that ADCC and complement action could be potential mechanisms (116). Alternatively, bispecific antibodies binding two distinct immune checkpoints, such as PD-1/PD-L1, CTLA-4, LAG-3 or TIM-3 are also interesting options to explore $(117,118)$. Besides, innate immune checkpoints are explored in bispecific antibody formats. Bispecific mAbs consisting of a low-affinity anti-CD47 arm combined with a high-affinity tumor antigen arm ensure that blockade of CD47 only occurs on tumor cells, which coexpress both antigens, resulting in improved phagocytosis of target cells and leaving healthy CD47 expressing cells unharmed (119). Bispecific antibodies show potent anti-tumor activity and warrant further study in combination with ablation. As Siglec receptors are regarded as novel immune checkpoints, it would be interesting to explore Siglec targeting antibodies in bi- or multispecific formats.

Alternatively, multispecificity can be achieved through the linking of recombinant receptors/ligands or immunomodulatory molecules to antibodies. To this end, endogenous $\operatorname{SIRP} \alpha$ domains are engrafted to a tumor antigen specific antibody $(120,121)$. 


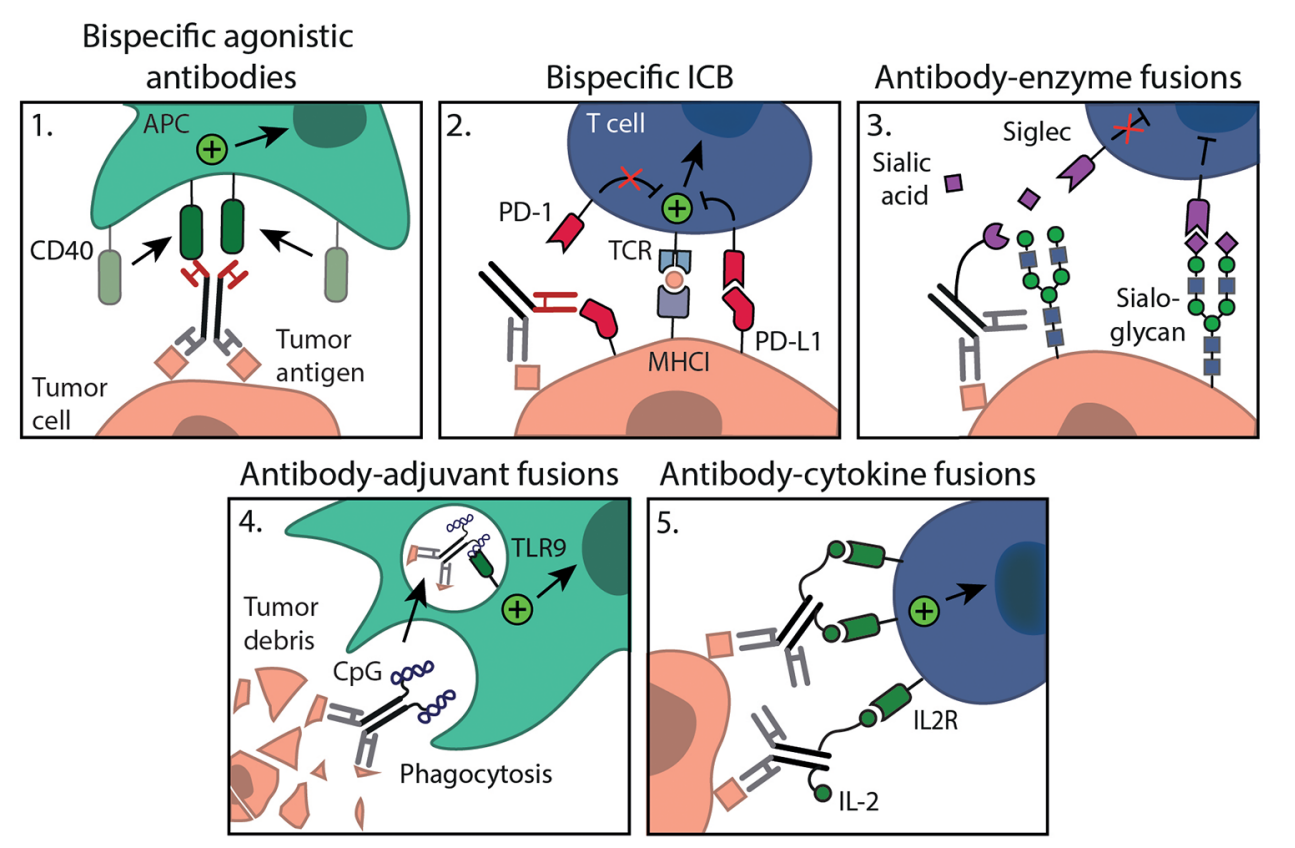

FIGURE 2 | Multifunctional antibody formats for combination with in situ tumor ablation. Administration of 1. bispecific agonistic antibodies (e.g. anti-MSLN-CD40) or 4. antibody-adjuvant fusions (e.g. chTNT3-CpG) will lead to local APC activation. Interventions such as 2. bispecific ICB (e.g. PD-L1xErbB2 antibody) may further stimulate myeloid as well as T cell immunity specifically within the TME; 3. antibody-enzyme fusions allow tumor specific sialoglycan degradation (e.g. anti-HER2 mAb-sialidase); 5. antibody-cytokine fusions (e.g. anti-GD2-IL2) will result in targeted cytokine delivery ensuring local immune cell activation, all are aimed at relieving local immunosuppression.

Binding of the antibody to tumor antigen specific cells allows binding of the SIRP $\alpha$ domain to CD47 on these same cells. Thereby, the interaction of CD47 with endogenous SIRP $\alpha$ expressed on myeloid cells is prevented, restoring the phagocytic capacity of myeloid cells $(120,121)$. In the context sialoglycan-Siglec axis, a recently developed multifunctional antibody consisting of a sialic acid-cleaving enzyme (sialidase) fused to an anti-HER2 antibody, aims to degrade sialoglycans in a tumor-specific manner (Figure 2.3) (122). In a syngeneic orthotopic HER2 ${ }^{+}$breast cancer model, anti-HER2 antibodysialidase conjugates delayed tumor growth and enhanced immune infiltration, leading to prolonged survival of mice. Using the HER2 ${ }^{+}$B16D5 melanoma tumor model and Siglec- $\mathrm{E}^{-/-}$mice, the authors showed that the effect was dependent on functional Siglec-E, a receptor highly expressed on tumor-infiltrating myeloid cells (122). These studies indicate that multifunctional antibodies aimed at reversing the immunosuppressive TME are potentially effective. Also, immune activation strategies, such as adjuvants can be incorporated into mAb conjugates (Figure 2.4). One such antibody is chTNT3$\mathrm{CpG}$, which is specific for extracellular DNA/histones (123), often present following ablative therapy. Systemic intraperitoneal (i.p.) administration of chTNT3-CpG resulted in delayed tumor development in both the Colon 26 adenocarcinoma and B16 tumor model, whereas i.p. administration of the chTNT3 antibody or $\mathrm{CpG}$ alone failed to show efficacy, again showing the added value of tumor targeting capacities of multifunctional mAbs (123).

Trafficking of APCs to the ablation site where they can capture and process antigens for (cross-) presentation is of importance for an in situ cancer vaccine. To this end, antibodies conjugated with DC growth factors, such as GMCSF or FLT3L, are of interest to expand and redirect DC subsets to the ablation site $(124,125)$. In fact, preclinical data showed that FLT3L in combination with RT in a mammary carcinoma model can help boost the abscopal effect (126). GM-CSF has been coupled to anti-HER2/neu and demonstrated anti-tumor activity in a HER2/neu expressing colon adenocarcinoma model (127). Several other cytokines including interleukin 2 (IL-2), IL12 and type I IFN have been fused to antibodies (Figure 2.5). The use of antibody-cytokine fusions has to potential to concentrate the cytokines at the tumor site, reducing side effects that are observed with systemic pro-inflammatory cytokine administration. IL-2, an important cytokine in the regulation of adaptive $\mathrm{T}$ cell responses, has been fused to diverse antibodies targeting relevant tumor proteins, such as hu14.18-IL2 targeting disialoganglioside GD2, huKS-IL2 targeting EpCAM, L19-IL2 targeting fibronectin and NHS-IL2 targeting histone/DNA complexes. IL-2 fusion antibodies were shown to improve responses to in situ tumor ablation, resulting in marked tumor reduction (128-130) and curative abscopal effects (131), mediated by $\mathrm{CD}^{+} \mathrm{T}$ cells. 
Preclinical research demonstrated that combination of 12 Gy RT together with five i.t. injections of hu14.18-IL2 on days 6 to 10 after RT eradicates constitutively GD2 expressing B78 melanoma tumors (132). In the $\sim 70 \%$ of mice that were rendered disease-free upon combination therapy, $90 \%$ rejected a re-challenge with GD2 ${ }^{\text {high }}$ B78 melanoma cells. This response of RT and hu14.18IL2 in melanoma could be augmented by addition of anti-CTLA-4 $\mathrm{mAb}$ (133). A recent study further pursued the combination of hu14.18-IL2 and RT as in situ cancer vaccination strategy. Voeller et al. demonstrated that neither RT plus hu14.18-IL2 therapy nor the addition of anti-CTLA-4 mAb to the combined therapy regimen caused significant growth inhibition in a GD2 $2^{\text {high }}$ nonimmunogenic 9464D neuroblastoma model (134). These observations suggest that the antibody-cytokine mediated therapeutic effect is tumor type dependent. Addition of the adjuvant CpG and anti-CD40 co-stimulatory agonist to the RT, $1 / 2$ dose hu14.18-IL2 (due to concern for significant toxicities) and anti-CTLA-4 mAb, improved tumor control and 80\% achieved complete tumor regression. A clinical phase II study recently demonstrated that hu14.18-IL2 given in combination with GMCSF and the differentiation inducing agent isotretinoin is safe and tolerable, and showed anti-tumor activity in patients with relapsed/ refractory neuroblastoma (135). Several other IL2-antibody fusions have advanced to clinical trials, including huKS-IL2 (136), NHSIL2 (128) and L19-IL2 (137). The combination of RT (5 x 4 Gy) followed by NHS-IL2 after first-line chemotherapy in metastatic non-small cell lung cancer (NSCLC) patients was well tolerated (128). A phase II trial will investigate the combination of SABRT and L19-IL2 therapy in metastatic NSCLC patients (137).

IL-12, an important $\mathrm{CD}^{+} \mathrm{T}$ cell and NK cell cytokine, has been fused to the anti-NHS antibody recognizing histone/DNA complexes. Enhanced tumor uptake of radiolabeled NHS-hIL12 was observed upon RT ablation in rhabdomyosarcoma xenografts (138). Fallon et al. showed that 0.36 Gy RT combined with subcutaneous NHS conjugated with murine IL12 resulted in superior tumor growth inhibition compared to either treatment alone in a murine LLC lung and MC38 colorectal cancer model (139). Studies combining other ablation types with NHS antibody cytokine fusions are not reported, however would be worthwhile to explore.

Besides interleukins, other pro-inflammatory cytokines, such as type I IFNs, have been coupled to various antibodies. IFN $\beta$ fused to anti-EGFR mAb limited growth of mouse EGFR-expressing B16 tumors which were unresponsive to anti-EGFR mAb therapy (140). Furthermore, multifunctional antibodies that simultaneously aim at activating the immune system and counteracting the immunosuppressive TME are promising for future cancer vaccine developments. To this end, anti-PD-L1 was armed with IFN $\alpha$ to simultaneously target both PD-L1 and the IFN-receptor. In different models, anti-PD-L1-IFN $\alpha$ could control advanced tumors as opposed to IFN $\alpha-F c$ or anti-PD-L1 monotherapy (141). In addition, multifunctional antibodies aimed at blockade of different immunosuppressive pathways are developed, such as the fusion protein M7824, comprising the extracellular domain of human TGF $\beta$ RII (TGF $\beta$ scavenging/trap) linked to the human anti-PDL1 heavy chain. Combination therapy with M7824 (intravenous, day
2) and RT (3.6 Gy per day, days 0-3) reduced primary as well as untreated secondary tumor growth relative to either treatment alone, indicating the induction of an abscopal effect (142). A phase I trial of M7824 showed a manageable safety profile in patients with heavily pretreated advanced solid tumors and encouraging treatment efficacy (143). Overall, multifunctional antibodies can be created by linking different immunomodulatory molecules with tumor or immune targeting mAbs. Proof-of-concept preclinical studies suggest therapeutic potential of different multifunctional antibody formats and clinical trials showed tolerability and safety. We anticipate that these multifunctional antibodies can work in concert with in situ tumor ablation and highlight them as a promising therapeutic strategy to explore.

\section{CONCLUSION}

In situ tumor ablation techniques allow for (neo)antigen loading of DCs without prior knowledge of tumor antigens or epitopes as in conventional DC vaccination. The induction of an efficient immune responses following ablation, however, requires addition of immune stimuli to eradicate local tumors and metastases and to provide long-term protection. Numerous immune activating strategies have shown to be suitable to act in concert with ablation generated tumor debris to achieve in situ cancer vaccination. More detailed knowledge about how effective immune activation strategies can work in concert with tumor ablation, such as timing and dose, is required to guide rationale ablation combination strategies. Although in situ ablation plus immune activating strategies ensure that the immune system is well instructed and initiated, the immunosuppressive environment that immune cells encounter upon arrival at the TME is still a potential bottleneck. Therefore, additional removal of inhibitory influences provides the possibility to further boost anti-tumor immune responses and enhance in situ ablation efficacy.

Multifunctional antibodies stimulating immune activation as well as counteracting immunosuppression can simultaneously affect multiple key processes in the anti-tumor immune response. They hold great promise for targeted cancer treatment with limited systemic toxicities and deserve further exploration as potential strategy to achieve a successful in situ cancer vaccine.

\section{AUTHOR CONTRIBUTIONS}

RB, FS and GA wrote the manuscript. JF, MV and LC reviewed the manuscript. All authors contributed to the article and approved the submitted version.

\section{FUNDING}

This work was supported by the foundation 'Villa Joep', a Radboud Institute for Molecular Life Sciences (RIMLS) PhD grant awarded to GA and a grant from the Dutch Cancer Foundation (KWF) awarded to GA (KUN2015-7604). 


\section{REFERENCES}

1. Ho NI. Huis In 't Veld LGM, Raaijmakers TK, Adema GJ. Adjuvants Enhancing Cross-Presentation by Dendritic Cells: The Key to More Effective Vaccines? Front Immunol (2018) 9:2874. doi: 10.3389/fimmu.2018.02874

2. den Brok MH, Sutmuller RP, Nierkens S, Bennink EJ, Toonen LW, Figdor CG, et al. Synergy between in situ cryoablation and TLR9 stimulation results in a highly effective in vivo dendritic cell vaccine. Cancer Res (2006) 66 (14):7285-92. doi: 10.1158/0008-5472.can-06-0206

3. Soanes WA, Ablin RJ, Gonder MJ. Remission of metastatic lesions following cryosurgery in prostatic cancer: immunologic considerations. J Urol (1970) 104(1):154-9. doi: 10.1016/s0022-5347(17)61690-2

4. Formenti SC, Demaria S. Systemic effects of local radiotherapy. Lancet Oncol (2009) 10(7):718-26. doi: 10.1016/\$1470-2045(09)70082-8

5. Alteber Z, Azulay M, Cafri G, Vadai E, Tzehoval E, Eisenbach L. Cryoimmunotherapy with local co-administration of ex vivo generated dendritic cells and CpG-ODN immune adjuvant, elicits a specific antitumor immunity. Cancer Immunol Immunother CII (2014) 63(4):369-80. doi: 10.1007/ s00262-014-1520-4

6. den Brok MH, Nierkens S, Wagenaars JA, Ruers TJ, Schrier CC, Rijke EO, et al. Saponin-based adjuvants create a highly effective anti-tumor vaccine when combined with in situ tumor destruction. Vaccine (2012) 30(4):737-44. doi: 10.1016/j.vaccine.2011.11.080

7. van den Bijgaart RJ, Eikelenboom DC, Hoogenboom M, Futterer JJ, den Brok MH, Adema GJ. Thermal and mechanical high-intensity focused ultrasound: perspectives on tumor ablation, immune effects and combination strategies. Cancer Immunol Immunother CII (2017) 66 (2):247-58. doi: 10.1007/s00262-016-1891-9

8. Brinkmann U, Kontermann RE. The making of bispecific antibodies. $m A b s$ (2017) 9(2):182-212. doi: 10.1080/19420862.2016.1268307

9. Begg AC, Stewart FA, Vens C. Strategies to improve radiotherapy with targeted drugs. Nat Rev Cancer (2011) 11(4):239-53. doi: 10.1038/nrc3007

10. Hall WA, Paulson ES, van der Heide UA, Fuller CD, Raaymakers BW, Lagendijk JJW, et al. The transformation of radiation oncology using realtime magnetic resonance guidance: A review. Eur J Cancer (2019) 122:42-52. doi: 10.1016/j.ejca.2019.07.021

11. Keisari Y. Tumor abolition and antitumor immunostimulation by physicochemical tumor ablation. Front Biosci (Landmark Ed) (2017) 22:310-47. doi: $10.2741 / 4487$

12. Hoogenboom M, Eikelenboom D, den Brok MH, Veltien A, Wassink M, Wesseling $\mathrm{P}$, et al. In vivo MR guided boiling histotripsy in a mouse tumor model evaluated by MRI and histopathology. NMR BioMed (2016) 29 (6):721-31. doi: 10.1002/nbm.3520

13. Khokhlova VA, Fowlkes JB, Roberts WW, Schade GR, Xu Z, Khokhlova TD, et al. Histotripsy methods in mechanical disintegration of tissue: towards clinical applications. Int J Hyperthermia (2015) 31(2):145-62. doi: 10.3109/ 02656736.2015.1007538

14. Hoogenboom M, Eikelenboom DC, van den Bijgaart RJE, Heerschap A, Wesseling $\mathrm{P}$, den Brok MH, et al. Impact of MR-guided boiling histotripsy in distinct murine tumor models. Ultrason Sonochem (2017) 38:1-8. doi: 10.1016/j.ultsonch.2017.02.035

15. Matsushita H, Vesely MD, Koboldt DC, Rickert CG, Uppaluri R, Magrini VJ, et al. Cancer exome analysis reveals a T-cell-dependent mechanism of cancer immunoediting. Nature (2012) 482(7385):400-4. doi: 10.1038/nature10755

16. Castle JC, Kreiter S, Diekmann J, Lower M, van de Roemer N, de Graaf J, et al. Exploiting the mutanome for tumor vaccination. Cancer Res (2012) 72 (5):1081-91. doi: 10.1158/0008-5472.CAN-11-3722

17. Bandyopadhyay S, Quinn TJ, Scandiuzzi L, Basu I, Partanen A, Tome WA, et al. Low-Intensity Focused Ultrasound Induces Reversal of TumorInduced $\mathrm{T}$ Cell Tolerance and Prevents Immune Escape. J Immunol (2016) 196(4):1964-76. doi: 10.4049/jimmunol.1500541

18. Hoogenboom M, Eikelenboom D, den Brok MH, Heerschap A, Futterer JJ, Adema GJ. Mechanical high-intensity focused ultrasound destruction of soft tissue: working mechanisms and physiologic effects. Ultrasound Med Biol (2015) 41(6):1500-17. doi: 10.1016/j.ultrasmedbio.2015.02.006

19. Hall TL, Kieran K, Ives K, Fowlkes JB, Cain CA, Roberts WW. Histotripsy of rabbit renal tissue in vivo: temporal histologic trends. J Endourol (2007) 21 (10):1159-66. doi: 10.1089/end.2007.9915
20. Shao Q, O'Flanagan S, Lam T, Roy P, Pelaez F, Burbach BJ, et al. Engineering $\mathrm{T}$ cell response to cancer antigens by choice of focal therapeutic conditions. Int J Hyperthermia (2019) 36(1):130-8. doi: 10.1080/02656736. 2018.1539253

21. Page DB, Yuan J, Redmond D, Wen YH, Durack JC, Emerson R, et al. Deep Sequencing of T-cell Receptor DNA as a Biomarker of Clonally Expanded TILs in Breast Cancer after Immunotherapy. Cancer Immunol Res (2016) 4 (10):835-44. doi: 10.1158/2326-6066.CIR-16-0013

22. den Brok MH, Nierkens S, Figdor CG, Ruers TJ, Adema GJ. Dendritic cells: tools and targets for antitumor vaccination. Expert Rev Vaccines (2005) 4 (5):699-710. doi: 10.1586/14760584.4.5.699

23. Nierkens S, den Brok MH, Garcia Z, Togher S, Wagenaars J, Wassink M, et al. Immune adjuvant efficacy of $\mathrm{CpG}$ oligonucleotide in cancer treatment is founded specifically upon TLR9 function in plasmacytoid dendritic cells. Cancer Res (2011) 71(20):6428-37. doi: 10.1158/0008-5472.CAN-11-2154

24. Noubade R, Majri-Morrison S, Tarbell KV. Beyond cDC1: Emerging Roles of DC Crosstalk in Cancer Immunity. Front Immunol (2019) 10:1014. doi: 10.3389/fimmu.2019.01014

25. Nierkens S, den Brok MH, Sutmuller RP, Grauer OM, Bennink E, Morgan $\mathrm{ME}$, et al. In vivo colocalization of antigen and CpG [corrected] within dendritic cells is associated with the efficacy of cancer immunotherapy. Cancer Res (2008) 68(13):5390-6. doi: 10.1158/0008-5472.can-07-6023

26. Nierkens S, den Brok MH, Roelofsen T, Wagenaars JA, Figdor CG, Ruers TJ, et al. Route of administration of the TLR9 agonist CpG critically determines the efficacy of cancer immunotherapy in mice. PloS One (2009) 4(12):e8368. doi: 10.1371/journal.pone.0008368

27. Veenstra JJ, Gibson HM, Littrup PJ, Reyes JD, Cher ML, Takashima A, et al. Cryotherapy with concurrent $\mathrm{CpG}$ oligonucleotide treatment controls local tumor recurrence and modulates HER2/neu immunity. Cancer Res (2014) 74(19):5409-20. doi: 10.1158/0008-5472.can-14-0501

28. Xu A, Zhang L, Yuan J, Babikr F, Freywald A, Chibbar R, et al. TLR9 agonist enhances radiofrequency ablation-induced CTL responses, leading to the potent inhibition of primary tumor growth and lung metastasis. Cell Mol Immunol (2019) 16(10):820-32. doi: 10.1038/s41423-018-0184-y

29. Monjazeb AM, Kent MS, Grossenbacher SK, Mall C, Zamora AE, Mirsoian A, et al. Blocking Indolamine-2,3-Dioxygenase Rebound Immune Suppression Boosts Antitumor Effects of Radio-Immunotherapy in Murine Models and Spontaneous Canine Malignancies. Clin Cancer Res Off J Am Assoc Cancer Res (2016) 22(17):4328-40. doi: 10.1158/10780432.ccr-15-3026

30. Chavez M, Silvestrini MT, Ingham ES, Fite BZ, Mahakian LM, Tam SM, et al. Distinct immune signatures in directly treated and distant tumors result from TLR adjuvants and focal ablation. Theranostics (2018) 8 (13):3611-28. doi: 10.7150/thno.25613

31. Blair TC, Bambina S, Alice AF, Kramer GF, Medler TR, Baird JR, et al. Dendritic Cell Maturation Defines Immunological Responsiveness of Tumors to Radiation Therapy. J Immunol (2020) 204(12):3416-24. doi: 10.4049/jimmunol.2000194

32. Yoshida S, Shime H, Takeda Y, Nam JM, Takashima K, Matsumoto M, et al. Toll-like receptor 3 signal augments radiation-induced tumor growth retardation in a murine model. Cancer Sci (2018) 109: (4):956-65. doi: $10.1111 /$ cas. 13543

33. Hammerich L, Marron TU, Upadhyay R, Svensson-Arvelund J, Dhainaut M, Hussein S, et al. Systemic clinical tumor regressions and potentiation of PD1 blockade with in situ vaccination. Nat Med (2019) 25(5):814-24. doi: 10.1038/s41591-019-0410-x

34. Schon MP, Schon M. TLR7 and TLR8 as targets in cancer therapy. Oncogene (2008) 27(2):190-9. doi: 10.1038/sj.onc.1210913

35. Chen Q, Chen J, Yang Z, Xu J, Xu L, Liang C, et al. Nanoparticle-Enhanced Radiotherapy to Trigger Robust Cancer Immunotherapy. Adv Mater (2019) 31(10):e1802228. doi: 10.1002/adma.201802228

36. Dewan MZ, Vanpouille-Box C, Kawashima N, DiNapoli S, Babb JS, Formenti SC, et al. Synergy of topical toll-like receptor 7 agonist with radiation and low-dose cyclophosphamide in a mouse model of cutaneous breast cancer. Clin Cancer Res Off J Am Assoc Cancer Res (2012) 18 (24):6668-78. doi: 10.1158/1078-0432.ccr-12-0984

37. Dovedi SJ, Adlard AL, Ota Y, Murata M, Sugaru E, Koga-Yamakawa E, et al. Intravenous administration of the selective toll-like receptor 7 agonist DSR- 
29133 leads to anti-tumor efficacy in murine solid tumor models which can be potentiated by combination with fractionated radiotherapy. Oncotarget (2016) 7(13):17035-46. doi: 10.18632/oncotarget.7928

38. Redondo P, del Olmo J, Lopez-Diaz de Cerio A, Inoges S, Marquina M, Melero I, et al. Imiquimod enhances the systemic immunity attained by local cryosurgery destruction of melanoma lesions. J Invest Dermatol (2007) 127 (7):1673-80. doi: 10.1038/sj.jid.5700777

39. Takagi H, Arimura K, Uto T, Fukaya T, Nakamura T, Choijookhuu N, et al. Plasmacytoid dendritic cells orchestrate TLR7-mediated innate and adaptive immunity for the initiation of autoimmune inflammation. Sci Rep (2016) 6:24477. doi: 10.1038/srep24477

40. Motwani M, Pesiridis S, Fitzgerald KA. DNA sensing by the cGAS-STING pathway in health and disease. Nat Rev Genet (2019) 20(11):657-74. doi: 10.1038/s41576-019-0151-1

41. Xu MM, Pu Y, Han D, Shi Y, Cao X, Liang H, et al. Dendritic Cells but Not Macrophages Sense Tumor Mitochondrial DNA for Cross-priming through Signal Regulatory Protein $\alpha$ Signaling. Immunity (2017) 47(2):363-73.e5. doi: 10.1016/j.immuni.2017.07.016

42. Deng L, Liang $\mathrm{H}, \mathrm{Xu}$ M, Yang X, Burnette B, Arina A, et al. STINGDependent Cytosolic DNA Sensing Promotes Radiation-Induced Type I Interferon-Dependent Antitumor Immunity in Immunogenic Tumors. Immunity (2014) 41(5):843-52. doi: 10.1016/j.immuni.2014.10.019

43. Luo M, Liu Z, Zhang X, Han C, Samandi LZ, Dong C, et al. Synergistic STING activation by PC7A nanovaccine and ionizing radiation improves cancer immunotherapy. J Controlled Release Off J Controlled Release Soc (2019) 300:154-60. doi: 10.1016/j.jconrel.2019.02.036

44. Schadt L, Sparano C, Schweiger NA, Silina K, Cecconi V, Lucchiari G, et al. Cancer-Cell-Intrinsic cGAS Expression Mediates Tumor Immunogenicity. Cell Rep (2019) 29(5):1236-48.e7. doi: 10.1016/ j.celrep.2019.09.065

45. Vanpouille-Box C, Alard A, Aryankalayil MJ, Sarfraz Y, Diamond JM, Schneider RJ. DNA exonuclease Trex1 regulates radiotherapy-induced tumour immunogenicity. Nat Commun (2017) 8:15618. doi: 10.1038/ ncomms 15618

46. Guey B, Wischnewski M, Decout A, Makasheva K, Kaynak M, Sakar MS, et al. BAF restricts cGAS on nuclear DNA to prevent innate immune activation. Science (2020) 369(6505):823-8. doi: 10.1126/science.aaw6421

47. McCauley ME, O’Rourke JG, Yáñez A, Markman JL, Ho R, Wang X, et al. C9orf72 in myeloid cells suppresses STING-induced inflammation. Nature (2020) 585(7823):96-101. doi: 10.1038/s41586-020-2625-x

48. Bakhoum SF, Ngo B, Laughney AM, Cavallo JA, Murphy CJ, Ly P, et al. Chromosomal instability drives metastasis through a cytosolic DNA response. Nature (2018) 553(7689):467-72. doi: 10.1038/nature25432

49. den Brok MH, Büll C, Wassink M, de Graaf AM, Wagenaars JA, Minderman $M$, et al. Saponin-based adjuvants induce cross-presentation in dendritic cells by intracellular lipid body formation. Nat Commun (2016) 7(1):13324. doi: $10.1038 /$ ncomms 13324

50. Raaijmakers TK, van den Bijgaart RJE, den Brok MH, Wassink M, de Graaf A, Wagenaars JA, et al. Tumor ablation plus co-administration of $\mathrm{CpG}$ and saponin adjuvants affects IL-1 production and multifunctional $\mathrm{T}$ cell numbers in tumor draining lymph nodes. J ImmunoTher Cancer (2020) 8(1):e000649. doi: 10.1136/jitc-2020-000649

51. Shin K-S, Jeon I, Kim B-S, Kim I-K, Park Y-J, Koh C-H, et al. MonocyteDerived Dendritic Cells Dictate the Memory Differentiation of CD8+ T Cells During Acute Infection. Front Immunol (2019) 10:1887. doi: 10.3389/ fimmu.2019.01887

52. Wakim LM, Waithman J, van Rooijen N, Heath WR, Carbone FR. Dendritic cell-induced memory $\mathrm{T}$ cell activation in nonlymphoid tissues. Science (2008) 319(5860):198-202. doi: 10.1126/science.1151869

53. Vonderheide RH. CD40 Agonist Antibodies in Cancer Immunotherapy. Annu Rev Med (2020) 71:47-58. doi: 10.1146/annurev-med-062518-045435

54. Schoenberger SP, Toes RE, van der Voort EI, Offringa R. Melief CJ. T-cell help for cytotoxic T lymphocytes is mediated by CD40-CD40L interactions. Nature (1998) 393(6684):480-3. doi: 10.1038/31002

55. Dovedi SJ, Lipowska-Bhalla G, Beers SA, Cheadle EJ, Mu L, Glennie MJ, et al. Antitumor Efficacy of Radiation plus Immunotherapy Depends upon Dendritic Cell Activation of Effector CD8+ T Cells. Cancer Immunol Res (2016) 4(7):621-30. doi: 10.1158/2326-6066.CIR-15-0253
56. Yasmin-Karim S, Bruck PT, Moreau M, Kunjachan S, Chen GZ, Kumar R, et al. Radiation and Local Anti-CD40 Generate an Effective in situ Vaccine in Preclinical Models of Pancreatic Cancer. Front Immunol (2018) 9:2030. doi: 10.3389/fimmu.2018.02030

57. Rech AJ, Dada H, Kotzin JJ, Henao-Mejia J, Minn AJ, Twyman-Saint Victor C, et al. Radiotherapy and CD40 Activation Separately Augment Immunity to Checkpoint Blockade in Cancer. Cancer Res (2018) 78(15):4282-91. doi: 10.1158/0008-5472.CAN-17-3821

58. Hellman P, Eriksson H. Early activation markers of human peripheral dendritic cells. Hum Immunol (2007) 68(5):324-33. doi: 10.1016/ j.humimm.2007.01.018

59. Krug A, Towarowski A, Britsch S, Rothenfusser S, Hornung V, Bals R, et al. Toll-like receptor expression reveals CPG DNA as a unique microbial stimulus for plasmacytoid dendritic cells which synergizes with CD40 ligand to induce high amounts of IL-12. Eur J Immunol (2001) 31 (10):3026-37. doi: 10.1002/1521-4141(2001010)31:10<3026::aidimmu3026>3.0.co; 2 -h

60. Ahonen CL, Doxsee CL, McGurran SM, Riter TR, Wade WF, Barth RJ, et al. and $\mathrm{CD} 40$ triggering induces potent $\mathrm{CD} 8+\mathrm{T}$ cell expansion with variable dependence on type I IFN. J Exp Med (2004) 199(6):775-84. doi: 10.1084/ jem. 20031591

61. Sanchez PJ, McWilliams JA, Haluszczak C, Yagita H, Kedl RM. Combined TLR/ CD40 Stimulation Mediates Potent Cellular Immunity by Regulating Dendritic Cell Expression of CD70 In Vivo. J Immunol (2007) 178(3):1564-72. doi: 10.4049/jimmunol.178.3.1564

62. Weinberg AD, Rivera MM, Prell R, Morris A, Ramstad T, Vetto JT, et al. Engagement of the OX-40 receptor in vivo enhances antitumor immunity. J Immunol (2000) 164(4):2160-9. doi: 10.4049/jimmunol.164.4.2160

63. Piconese S, Valzasina B, Colombo MP. OX40 triggering blocks suppression by regulatory T cells and facilitates tumor rejection. J Exp Med (2008) 205 (4):825-39. doi: 10.1084/jem.20071341

64. Roberts DJ, Franklin NA, Kingeter LM, Yagita H, Tutt AL, Glennie MJ, et al. Control of established melanoma by CD27 stimulation is associated with enhanced effector function and persistence, and reduced PD-1 expression of tumor infiltrating CD8(+) T cells. J Immunother (Hagerstown Md 1997) (2010) 33(8):769-79. doi: 10.1097/CJI.0b013e3181ee238f

65. Eskiocak U, Guzman W, Wolf B, Cummings C, Milling L, Wu H-J, et al. Differentiated agonistic antibody targeting CD137 eradicates large tumors without hepatotoxicity. JCI Insight (2020) 5(5):e133647. doi: 10.1172/ jci.insight. 133647

66. Yokouchi H, Yamazaki K, Chamoto K, Kikuchi E, Shinagawa N, Oizumi S, et al. Anti-OX40 monoclonal antibody therapy in combination with radiotherapy results in therapeutic antitumor immunity to murine lung cancer. Cancer Sci (2008) 99(2):361-7. doi: 10.1111/j.13497006.2007.00664.x

67. Niknam S, Barsoumian HB, Schoenhals JE, Jackson HL, Yanamandra N, Caetano MS, et al. Radiation Followed by OX40 Stimulation Drives Local and Abscopal Antitumor Effects in an Anti-PD1-Resistant Lung Tumor Model. Clin Cancer Res Off J Am Assoc Cancer Res (2018) 24(22):5735-43. doi: 10.1158/1078-0432.ccr-17-3279

68. Rodriguez-Ruiz ME, Rodriguez I, Garasa S, Barbes B, Solorzano JL, PerezGracia JL, et al. Abscopal Effects of Radiotherapy Are Enhanced by Combined Immunostimulatory mAbs and Are Dependent on CD8 T Cells and Crosspriming. Cancer Res (2016) 76(20):5994-6005. doi: 10.1158/00085472.CAN-16-0549

69. Verbrugge I, Hagekyriakou J, Sharp LL, Galli M, West A, McLaughlin NM, et al. Radiotherapy increases the permissiveness of established mammary tumors to rejection by immunomodulatory antibodies. Cancer Res (2012) 72 (13):3163-74. doi: 10.1158/0008-5472.CAN-12-0210

70. Sagiv-Barfi I, Czerwinski DK, Levy S, Alam IS, Mayer AT, Gambhir SS, et al. Eradication of spontaneous malignancy by local immunotherapy. Sci Trans Med (2018) 10(426):eaan4488. doi: 10.1126/scitranslmed.aan4488

71. Buhtoiarov IN, Lum HD, Berke G, Sondel PM, Rakhmilevich AL. Synergistic Activation of Macrophages via CD40 and TLR9 Results in T Cell Independent Antitumor Effects. J Immunol (2006) 176(1):309-18. doi: 10.4049/jimmunol.176.1.309

72. Lindau D, Gielen P, Kroesen M, Wesseling P, Adema GJ. The immunosuppressive tumour network: myeloid-derived suppressor cells, 
regulatory T cells and natural killer T cells. Immunology (2013) 138(2):10515. doi: $10.1111 / \mathrm{imm} .12036$

73. Umansky V, Adema GJ, Baran J, Brandau S, Van Ginderachter JA, Hu X, et al. Interactions among myeloid regulatory cells in cancer. Cancer Immunol Immunother (2019) 68(4):645-60. doi: 10.1007/s00262-018-2200-6

74. Butt AQ, Mills KH. Immunosuppressive networks and checkpoints controlling antitumor immunity and their blockade in the development of cancer immunotherapeutics and vaccines. Oncogene (2014) 33(38):4623-31. doi: 10.1038/onc.2013.432

75. Vesely MD, Kershaw MH, Schreiber RD, Smyth MJ. Natural innate and adaptive immunity to cancer. Annu Rev Immunol (2011) 29:235-71. doi: 10.1146/annurev-immunol-031210-101324

76. Barcellos-Hoff MH, Derynck R, Tsang ML, Weatherbee JA. Transforming growth factor-beta activation in irradiated murine mammary gland. J Clin Invest (1994) 93(2):892-9. doi: 10.1172/jci117045

77. Jobling MF, Mott JD, Finnegan MT, Jurukovski V, Erickson AC, Walian PJ, et al. Isoform-specific activation of latent transforming growth factor beta (LTGF-beta) by reactive oxygen species. Radiat Res (2006) 166 (6):839-48. doi: $10.1667 / \mathrm{rr} 0695.1$

78. Vanpouille-Box C, Diamond JM, Pilones KA, Zavadil J, Babb JS, Formenti SC, et al. TGF $\beta$ Is a Master Regulator of Radiation Therapy-Induced Antitumor Immunity. Cancer Res (2015) 75(11):2232-42. doi: 10.1158/ 0008-5472.can-14-3511

79. Zhu H, Gu X, Xia L, Zhou Y, Bouamar H, Yang J, et al. A Novel TGF $\beta$ Trap Blocks Chemotherapeutics-Induced TGF $\beta 1$ Signaling and Enhances Their Anticancer Activity in Gynecologic Cancers. Clin Cancer Res Off J Am Assoc Cancer Res (2018) 24(12):2780-93. doi: 10.1158/1078-0432.ccr-17-3112

80. Penn JW, Grobbelaar AO, Rolfe KJ. The role of the TGF-beta family in wound healing, burns and scarring: a review. Int J Burns Trauma (2012) 2 (1):18-28.

81. Bouquet F, Pal A, Pilones KA, Demaria S, Hann B, Akhurst RJ, et al. TGF $\beta 1$ inhibition increases the radiosensitivity of breast cancer cells in vitro and promotes tumor control by radiation in vivo. Clin Cancer Res Off J Am Assoc Cancer Res (2011) 17(21):6754-65. doi: 10.1158/1078-0432.ccr-11-0544

82. Mannino MH, Zhu Z, Xiao H, Bai Q, Wakefield MR, Fang Y. The paradoxical role of IL-10 in immunity and cancer. Cancer Lett (2015) 367 (2):103-7. doi: 10.1016/j.canlet.2015.07.009

83. Mumm JB, Emmerich J, Zhang X, Chan I, Wu L, Mauze S, et al. IL-10 Elicits IFN $\gamma$-Dependent Tumor Immune Surveillance. Cancer Cell (2011) 20 (6):781-96. doi: 10.1016/j.ccr.2011.11.003

84. Qiao J, Liu Z, Dong C, Luan Y, Zhang A, Moore C, et al. Targeting Tumors with IL-10 Prevents Dendritic Cell-Mediated CD8+ T Cell Apoptosis. Cancer Cell (2019) 35(6):901-15.e4. doi: 10.1016/j.ccell.2019.05.005

85. Sharma P, Allison JP. Immune checkpoint targeting in cancer therapy: toward combination strategies with curative potential. Cell (2015) 161 (2):205-14. doi: 10.1016/j.cell.2015.03.030

86. Wei SC, Duffy CR, Allison JP. Fundamental Mechanisms of Immune Checkpoint Blockade Therapy. Cancer Discovery (2018) 8(9):1069-86. doi: 10.1158/2159-8290.CD-18-0367

87. Wang XY, Zuo D, Sarkar D, Fisher PB. Blockade of cytotoxic T-lymphocyte antigen-4 as a new therapeutic approach for advanced melanoma. Expert Opin Pharmacother (2011) 12(17):2695-706. doi: 10.1517/ 14656566.2011.629187

88. Simpson TR, Li F, Montalvo-Ortiz W, Sepulveda MA, Bergerhoff K, Arce F, et al. Fc-dependent depletion of tumor-infiltrating regulatory $\mathrm{T}$ cells codefines the efficacy of anti-CTLA-4 therapy against melanoma. J Exp Med (2013) 210(9):1695-710. doi: 10.1084/jem.20130579

89. den Brok MH, Sutmuller RP, Nierkens S, Bennink EJ, Frielink C, Toonen LW, et al. Efficient loading of dendritic cells following cryo and radiofrequency ablation in combination with immune modulation induces anti-tumour immunity. Br J Cancer (2006) 95(7):896-905. doi: 10.1038/ sj.bjc.6603341

90. Waitz R, Solomon SB, Petre EN, Trumble AE, Fasso M, Norton L, et al. Potent induction of tumor immunity by combining tumor cryoablation with anti-CTLA-4 therapy. Cancer Res (2012) 72(2):430-9. doi: 10.1158/00085472.CAN-11-1782

91. Zhang L, Wang J, Jiang J, Zhang M, Shen J. CTLA-4 Blockade Suppresses Progression of Residual Tumors and Improves Survival After Insufficient
Radiofrequency Ablation in a Subcutaneous Murine Hepatoma Model. Cardiovasc Intervent Radiol (2020) 43(9):1353-61. doi: 10.1007/s00270020-02505-6

92. McArthur HL, Diab A, Page DB, Yuan J, Solomon SB, Sacchini V, et al. A Pilot Study of Preoperative Single-Dose Ipilimumab and/or Cryoablation in Women with Early-Stage Breast Cancer with Comprehensive Immune Profiling. Clin Cancer Res Off J Am Assoc Cancer Res (2016) 22(23):572937. doi: 10.1158/1078-0432.CCR-16-0190

93. Ji D, Song C, Li Y, Xia J, Wu Y, Jia J, et al. Combination of radiotherapy and suppression of Tregs enhances abscopal antitumor effect and inhibits metastasis in rectal cancer. J Immunother Cancer (2020) 8(2):e000826. doi: 10.1136/jitc-2020-000826

94. Oweida AJ, Darragh L, Phan A, Binder D, Bhatia S, Mueller A, et al. STAT3 Modulation of Regulatory T Cells in Response to Radiation Therapy in Head and Neck Cancer. J Natl Cancer Inst (2019) 111(12):1339-49. doi: 10.1093/ jnci/djz036

95. Deng L, Liang H, Burnette B, Beckett M, Darga T, Weichselbaum RR, et al. Irradiation and anti-PD-L1 treatment synergistically promote antitumor immunity in mice. J Clin Invest (2014) 124(2):687-95. doi: 10.1172/JCI67313

96. Eranki A, Srinivasan P, Ries M, Kim A, Lazarski CA, Rossi CT, et al. HighIntensity Focused Ultrasound (HIFU) Triggers Immune Sensitization of Refractory Murine Neuroblastoma to Checkpoint Inhibitor Therapy. Clin Cancer Res Off J Am Assoc Cancer Res (2020) 26(5):1152-61. doi: 10.1158/ 1078-0432.CCR-19-1604

97. Shi L, Chen L, Wu C, Zhu Y, Xu B, Zheng X, et al. PD-1 Blockade Boosts Radiofrequency Ablation-Elicited Adaptive Immune Responses against Tumor. Clin Cancer Res Off J Am Assoc Cancer Res (2016) 22(5):1173-84. doi: 10.1158/1078-0432.CCR-15-1352

98. Shi L, Wang J, Ding N, Zhang Y, Zhu Y, Dong S, et al. Inflammation induced by incomplete radiofrequency ablation accelerates tumor progression and hinders PD-1 immunotherapy. Nat Commun (2019) 10(1):5421. doi: 10.1038/s41467-019-13204-3

99. Twyman-Saint Victor C, Rech AJ, Maity A, Rengan R, Pauken KE, Stelekati E, et al. Radiation and dual checkpoint blockade activate non-redundant immune mechanisms in cancer. Nature (2015) 520(7547):373-7. doi: 10.1038/nature14292

100. Dewan MZ, Galloway AE, Kawashima N, Dewyngaert JK, Babb JS, Formenti $\mathrm{SC}$, et al. Fractionated but not single-dose radiotherapy induces an immunemediated abscopal effect when combined with anti-CTLA-4 antibody. Clin Cancer Res Off J Am Assoc Cancer Res (2009) 15(17):5379-88. doi: 10.1158/ 1078-0432.CCR-09-0265

101. Demaria S, Kawashima N, Yang AM, Devitt ML, Babb JS, Allison JP, et al. Immune-mediated inhibition of metastases after treatment with local radiation and CTLA-4 blockade in a mouse model of breast cancer. Clin Cancer Res Off J Am Assoc Cancer Res (2005) 11(2 Pt 1):728-34.

102. Dovedi SJ, Adlard AL, Lipowska-Bhalla G, McKenna C, Jones S, Cheadle EJ, et al. Acquired resistance to fractionated radiotherapy can be overcome by concurrent PD-L1 blockade. Cancer Res (2014) 74(19):5458-68. doi: 10.1158/0008-5472.CAN-14-1258

103. Murray D, McBride WH, Schwartz JL. Radiation biology in the context of changing patterns of radiotherapy. Radiat Res (2014) 182(3):259-72. doi: 10.1667/RR13740.1

104. Qin S, Xu L, Yi M, Yu S, Wu K, Luo S. Novel immune checkpoint targets: moving beyond PD-1 and CTLA-4. Mol Cancer (2019) 18(1):155. doi: 10.1186/s12943-019-1091-2

105. van de Wall S, Santegoets KCM, van Houtum EJH, Bull C, Adema GJ. Sialoglycans and Siglecs Can Shape the Tumor Immune Microenvironment. Trends Immunol (2020) 41(4):274-85. doi: 10.1016/j.it.2020.02.001

106. Bull C, Boltje TJ, Balneger N, Weischer SM, Wassink M, van Gemst JJ, et al. Sialic Acid Blockade Suppresses Tumor Growth by Enhancing T-cellMediated Tumor Immunity. Cancer Res (2018) 78(13):3574-88. doi: 10.1158/0008-5472.CAN-17-3376

107. Veillette A, Chen J. SIRPalpha-CD47 Immune Checkpoint Blockade in Anticancer Therapy. Trends Immunol (2018) 39(3):173-84. doi: 10.1016/ j.it.2017.12.005

108. Liu X, Pu Y, Cron K, Deng L, Kline J, Frazier WA, et al. CD47 blockade triggers T cell-mediated destruction of immunogenic tumors. Nat Med (2015) 21(10):1209-15. doi: 10.1038/nm.3931 
109. Tseng D, Volkmer JP, Willingham SB, Contreras-Trujillo H, Fathman JW, Fernhoff NB, et al. Anti-CD47 antibody-mediated phagocytosis of cancer by macrophages primes an effective antitumor T-cell response. Proc Natl Acad Sci USA (2013) 110(27):11103-8. doi: 10.1073/pnas.1305569110

110. Soto-Pantoja DR, Terabe M, Ghosh A, Ridnour LA, DeGraff WG, Wink DA, et al. CD47 in the tumor microenvironment limits cooperation between antitumor T-cell immunity and radiotherapy. Cancer Res (2014) 74 (23):6771-83. doi: 10.1158/0008-5472.CAN-14-0037-T

111. Labrijn AF, Janmaat ML, Reichert JM, Parren PWHI. Bispecific antibodies: a mechanistic review of the pipeline. Nat Rev Drug Discov (2019) 18 (8):585-608. doi: 10.1038/s41573-019-0028-1

112. Lu L, Liu N, Fan K, Zhang G, Li C, Yan Y, et al. A tetravalent single chain diabody (CD40/HER2) efficiently inhibits tumor proliferation through recruitment of T cells and anti-HER2 functions. Mol Immunol (2019) 109:149-56. doi: 10.1016/j.molimm.2019.03.001

113. Ye S, Cohen D, Belmar NA, Choi D, Tan SS, Sho M, et al. A Bispecific Molecule Targeting CD40 and Tumor Antigen Mesothelin Enhances Tumor-Specific Immunity. Cancer Immunol Res (2019) 7(11):1864-75. doi: 10.1158/2326-6066.cir-18-0805

114. Gaspar M, Pravin J, Rodrigues L, Uhlenbroich S, Everett KL, Wollerton F, et al. CD137/OX40 Bispecific Antibody Induces Potent Antitumor Activity that Is Dependent on Target Coengagement. Cancer Immunol Res (2020) 8 (6):781-93. doi: 10.1158/2326-6066.cir-19-0798

115. Kvarnhammar AM, Veitonmäki N, Hägerbrand K, Dahlman A, Smith KE, Fritzell S, et al. The CTLA-4 x OX40 bispecific antibody ATOR-1015 induces anti-tumor effects through tumor-directed immune activation. J ImmunoTher Cancer (2019) 7(1):103. doi: 10.1186/s40425-019-0570-8

116. Mittal D, Vijayan D, Neijssen J, Kreijtz J, Habraken M, Van Eenennaam H, et al. Blockade of ErbB2 and PD-L1 using a bispecific antibody to improve targeted anti-ErbB2 therapy. Oncoimmunology (2019) 8(11):e1648171. doi: 10.1080/2162402X.2019.1648171

117. LaMotte-Mohs R, Shah K, Smith D, Gorlatov S, Ciccarone V, Tamura J, et al. MGD013, a bispecific PD-1 x LAG-3 Dual-Affinity Re-Targeting (DART ${ }^{\circledR}$ ) protein with T-cell immunomodulatory activity for cancer treatment. Cancer Res (2016) 76(Suppl. 14):3217.

118. Kraman M, Faroudi M, Allen NL, Kmiecik K, Gliddon D, Seal C, et al. FS118, a Bispecific Antibody Targeting LAG-3 and PD-L1, Enhances T-Cell Activation Resulting in Potent Antitumor Activity. Clin Cancer Res Off J Am Assoc Cancer Res (2020) 26(13):3333-44. doi: 10.1158/1078-0432.CCR19-3548

119. Dheilly E, Moine V, Broyer L, Salgado-Pires S, Johnson Z, Papaioannou A, et al. Selective Blockade of the Ubiquitous Checkpoint Receptor CD47 Is Enabled by Dual-Targeting Bispecific Antibodies. Mol Ther (2017) 25 (2):523-33. doi: 10.1016/j.ymthe.2016.11.006

120. Piccione EC, Juarez S, Tseng S, Liu J, Stafford M, Narayanan C, et al. SIRPalpha-Antibody Fusion Proteins Selectively Bind and Eliminate Dual Antigen-Expressing Tumor Cells. Clin Cancer Res Off J Am Assoc Cancer Res (2016) 22(20):5109-19. doi: 10.1158/1078-0432.CCR-15-2503

121. Ponce LP, Fenn NC, Moritz N, Krupka C, Kozik JH, Lauber K, et al. SIRPalphaantibody fusion proteins stimulate phagocytosis and promote elimination of acute myeloid leukemia cells. Oncotarget (2017) 8(7):11284-301. doi: 10.18632/ oncotarget. 14500

122. Gray MA, Stanczak MA, Mantuano NR, Xiao H, Pijnenborg JFA, Malaker SA, et al. Targeted glycan degradation potentiates the anticancer immune response in vivo. Nat Chem Biol (2020) 16(12):1376-84. doi: 10.1038/ s41589-020-0622-x

123. Jang JK, Khawli LA, Canter DC, Hu P, Zhu TH, Wu BW, et al. Systemic delivery of chTNT-3/CpG immunoconjugates for immunotherapy in murine solid tumor models. Cancer Immunol Immunother CII (2016) 65(5):511-23. doi: 10.1007/s00262-016-1813-x

124. Merad M, Sugie T, Engleman EG, Fong L. In vivo manipulation of dendritic cells to induce therapeutic immunity. Blood (2002) 99(5):1676-82. doi: 10.1182/blood.v99.5.1676

125. Pulendran B, Banchereau J, Burkeholder S, Kraus E, Guinet E, Chalouni C, et al. Flt3-ligand and granulocyte colony-stimulating factor mobilize distinct human dendritic cell subsets in vivo. J Immunol (2000) 165(1):566-72. doi: 10.4049/jimmunol.165.1.566
126. Demaria S, Ng B, Devitt ML, Babb JS, Kawashima N, Liebes L, et al. Ionizing radiation inhibition of distant untreated tumors (abscopal effect) is immune mediated. Int J Radiat Oncol Biol Phys (2004) 58(3):862-70. doi: 10.1016/ j.ijrobp.2003.09.012

127. Dela Cruz JS, Trinh KR, Morrison SL, Penichet ML. Recombinant antihuman HER2/neu IgG3-(GM-CSF) fusion protein retains antigen specificity and cytokine function and demonstrates antitumor activity. I Immunol (2000) 165(9):5112-21. doi: 10.4049/jimmunol.165.9.5112

128. van den Heuvel MM, Verheij M, Boshuizen R, Belderbos J, Dingemans AM, De Ruysscher D, et al. NHS-IL2 combined with radiotherapy: preclinical rationale and phase Ib trial results in metastatic non-small cell lung cancer following first-line chemotherapy. J Transl Med (2015) 13:32. doi: 10.1186/ s12967-015-0397-0

129. Johnson EE, Yamane BH, Buhtoiarov IN, Lum HD, Rakhmilevich AL, Mahvi DM, et al. Radiofrequency ablation combined with KS-IL2 immunocytokine (EMD 273066) results in an enhanced antitumor effect against murine colon adenocarcinoma. Clin Cancer Res Off J Am Assoc Cancer Res (2009) 15 (15):4875-84. doi: 10.1158/1078-0432.CCR-09-0110

130. Zegers CM, Rekers NH, Quaden DH, Lieuwes NG, Yaromina A, Germeraad WT, et al. Radiotherapy combined with the immunocytokine L19-IL2 provides long-lasting antitumor effects. Clin Cancer Res Off J Am Assoc Cancer Res (2015) 21(5):1151-60. doi: 10.1158/1078-0432.CCR-14-2676

131. Rekers NH, Olivo Pimentel V, Yaromina A, Lieuwes NG, Biemans R, Zegers CML, et al. The immunocytokine L19-IL2: An interplay between radiotherapy and long-lasting systemic anti-tumour immune responses. Oncoimmunology (2018) 7(4):e1414119. doi: 10.1080/ 2162402X.2017.1414119

132. Morris ZS, Guy EI, Francis DM, Gressett MM, Werner LR, Carmichael LL, et al. In Situ Tumor Vaccination by Combining Local Radiation and TumorSpecific Antibody or Immunocytokine Treatments. Cancer Res (2016) 76 (13):3929-41. doi: 10.1158/0008-5472.CAN-15-2644

133. Morris ZS, Guy EI, Werner LR, Carlson PM, Heinze CM, Kler JS, et al. Tumor-Specific Inhibition of In Situ Vaccination by Distant Untreated Tumor Sites. Cancer Immunol Res (2018) 6(7):825-34. doi: 10.1158/23266066.CIR-17-0353

134. Voeller J, Erbe AK, Slowinski J, Rasmussen K, Carlson PM, Hoefges A, et al. Combined innate and adaptive immunotherapy overcomes resistance of immunologically cold syngeneic murine neuroblastoma to checkpoint inhibition. J Immunother Cancer (2019) 7(1):344. doi: 10.1186/s40425-0190823-6

135. Shusterman S, Naranjo A, Van Ryn C, Hank JA, Parisi MT, Shulkin BL, et al. Antitumor Activity and Tolerability of hu14.18-IL2 with GMCSF and Isotretinoin in Recurrent or Refractory Neuroblastoma: A Children's Oncology Group Phase II Study. Clin Cancer Res Off J Am Assoc Cancer Res (2019) 25(20):6044-51. doi: 10.1158/1078-0432.CCR-19-0798

136. Connor JP, Cristea MC, Lewis NL, Lewis LD, Komarnitsky PB, Mattiacci $\mathrm{MR}$, et al. A phase $1 \mathrm{~b}$ study of humanized KS-interleukin-2 (huKS-IL2) immunocytokine with cyclophosphamide in patients with EpCAM-positive advanced solid tumors. BMC Cancer (2013) 13:20. doi: 10.1186/1471-240713-20

137. Lieverse RIY, Van Limbergen EJ, Oberije CJG, Troost EGC, Hadrup SR, Dingemans AC, et al. Stereotactic ablative body radiotherapy (SABR) combined with immunotherapy (L19-IL2) versus standard of care in stage IV NSCLC patients, ImmunoSABR: a multicentre, randomised controlled open-label phase II trial. BMC Cancer (2020) 20(1):557. doi: 10.1186/s12885020-07055-1

138. Eckert F, Schmitt J, Zips D, Krueger MA, Pichler BJ, Gillies SD, et al. Enhanced binding of necrosis-targeting immunocytokine NHS-IL12 after local tumour irradiation in murine xenograft models. Cancer Immunol Immunother (2016) 65(8):1003-13. doi: 10.1007/s00262-016-1863-0

139. Fallon J, Tighe R, Kradjian G, Guzman W, Bernhardt A, Neuteboom B, et al. The immunocytokine NHS-IL12 as a potential cancer therapeutic. Oncotarget (2014) 5(7):1869-84. doi: 10.18632/oncotarget.1853

140. Yang X, Zhang X, Fu ML, Weichselbaum RR, Gajewski TF, Guo Y, et al. Targeting the tumor microenvironment with interferon-beta bridges innate and adaptive immune responses. Cancer Cell (2014) 25(1):37-48. doi: 10.1016/j.ccr.2013.12.004 
141. Liang Y, Tang H, Guo J, Qiu X, Yang Z, Ren Z, et al. Targeting IFNalpha to tumor by anti-PD-L1 creates feedforward antitumor responses to overcome checkpoint blockade resistance. Nat Commun (2018) 9(1):4586. doi: 10.1038/s41467-018-06890-y

142. Lan Y, Zhang D, Xu C, Hance KW, Marelli B, Qi J, et al. Enhanced preclinical antitumor activity of M7824, a bifunctional fusion protein simultaneously targeting PD-L1 and TGF-beta. Sci Transl Med (2018) 10(424):eaan5488. doi: $10.1126 /$ scitranslmed.aan 5488

143. Strauss J, Heery CR, Schlom J, Madan RA, Cao L, Kang Z, et al. Phase I Trial of M7824 (MSB0011359C), a Bifunctional Fusion Protein Targeting PD-L1 and TGFbeta, in Advanced Solid Tumors. Clin Cancer Res Off J Am Assoc Cancer Res (2018) 24(6):1287-95. doi: 10.1126/scitranslmed.aan5488
Conflict of Interest: The authors declare that the research was conducted in the absence of any commercial or financial relationships that could be construed as a potential conflict of interest.

Copyright $\odot 2021$ van den Bijgaart, Schuurmans, Fütterer, Verheij, Cornelissen and Adema. This is an open-access article distributed under the terms of the Creative Commons Attribution License (CC BY). The use, distribution or reproduction in other forums is permitted, provided the original author(s) and the copyright owner(s) are credited and that the original publication in this journal is cited, in accordance with accepted academic practice. No use, distribution or reproduction is permitted which does not comply with these terms. 